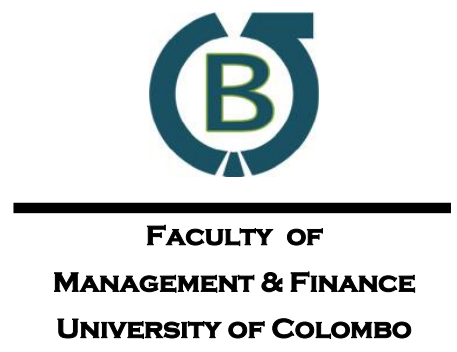

Colombo Business Journal

INTERNATIONAL JOURNAL OF

THEORY \& PRACTICE

Vol. 08, No. 01, June, 2017

\title{
The Study of Professional Training to Improve Customer Satisfaction in Small and Medium Scale Hotels in Sri Lanka
}

\author{
Kalpana R. Ambepitiya ${ }^{\text {a1 }}$, Upul Rohana Dharmasirib \\ ${ }^{a}$ Department of Management and Finance, General Sir John Kotelawala Defence University, Sri Lanka. \\ ${ }^{b}$ Postgraduate Diploma Programme, General Sir John Kotelawala Defence University, Sri Lanka
}

\begin{abstract}
Sri Lanka is currently in the stage of rebuilding its economy after three decades of civil war. One of the major focuses in this development endeavour is the leisure and hotel industry. Therefore, opportunities are open for international hotel chains as well as small providers. Small and medium scale hotels face many challenges in operating their businesses economically. Retention of customers is one of the major problems faced by those engaged in this sector. This study discusses the effects of professional training to ensure the satisfaction of customers in small and medium scale hotels in Sri Lanka. In collecting data, two questionnaires were distributed between two samples of respondents. One sample comprised 53 employees from 10 small and medium hotels while the other sample comprised of 30 local and foreign customers. This study indicates that professional training of employees has a direct impact on building customer satisfaction in small and medium scale hotels in Sri Lanka. Both customers and the employees believe that when the professional training is high, the quality of service at these hotels also increases. Thus, it indicates that providing continuous professional training is beneficial to the organization and to the individual concerned. A well-trained employee can increase customer satisfaction and repetition of purchase.
\end{abstract}

Keywords: Professional Training, Customer Satisfaction, Quality of Service, Small and Medium Hotels.

\section{Introduction}

Since the twelfth century, many explorers have identified Sri Lanka as one of the finest islands in the whole world. For decades, it has been a travel destination for different travellers 
from around the world. The civil war had a negative impact on the tourism industry for 30 years. During this period, the industry stagnated until the end of war in 2009. With new hopes about development, the country now has a strategic plan to move the economy forward in the next few years. Tourism is one of the areas selected for this plan that is expected to bring more foreign income to the country. New opportunities are available for local and international investors who have been invited to participate in this development drive. In 2012, Post Office Worldwide Holiday Costs Barometer named Sri Lanka, the best-valued destination for holidays (Travel Mail Reporter, 2013), helping to increase tourist arrivals to Sri Lanka, which exceeded 1.5 million in 2015 (Sri Lanka Tourism Development Authority, 2016).

The tourism industry is booming at a rapid scale in Sri Lanka and the number of tourists per year has increased. With the intention of attracting foreign investors and tourists to the island, Sri Lanka has focused on opening more resorts, hotels and spas and developing infrastructure facilities. The target to achieve 2.5 million tourists by 2016 has led this rapid development (Sri Lanka Tourism Development Authority, 2011). The government of Sri Lanka has launched certain development projects targeting the development of this entire sector, covering all tourism destinations in Sri Lanka. Some mega development projects were launched under the ministries of Nation Building, Economic Development and the Central Bank with the hopes of adding an advantage to the fulfilment of the vision in tourism industry. The floor is open to not only the large-scale international hotel chains, but also to small and medium scale hotels operated by locals.

Figure 1 is a comparison of tourist visits to Sri Lanka in years 2015 and 2016. There is an increase in 2016 compared to visits made in 2015. This indicates that Sri Lanka is in a position to expand the service quality of the tourism industry tangibly as well as intangibly. One of the tangible aspects of service quality is the design of the hotel. There is growing evidence that hotel design has both marketing and strategic implications. Average daily room rate, occupancy, and revenue per available room are all positively related to good hotel design (Alsaqre, 2011). Other tangible aspects are ambient conditions that can include colour, music, lighting, seating comfort and overall cleanliness of the places inside the hotels. It has been confirmed that all of these items have their effect on customers' perceptions and responses to the environment (Baker \& Collier, 2005; Parasuraman, Berry, \& Zeithamal, 1988). The dimensions of intangibles in service quality are reliability, responsiveness, assurance and empathy. The dimension of reliability is defined as delivering the promised performance dependably and accurately (Schneider \& White, 2004). While the dimension of responsiveness is defined as willingness of the organization to provide prompt service and help customers, the dimension of assurance is defined as ability of the organization's employees to inspire trust and confidence in the organization through their 
knowledge and courtesy and the dimension of empathy is defined as personalized attention given to a customer (Parasuraman et al., 1988).

\section{Figure 1: Comparison of Tourists' Visits to Sri Lanka in 2015 and 2016}

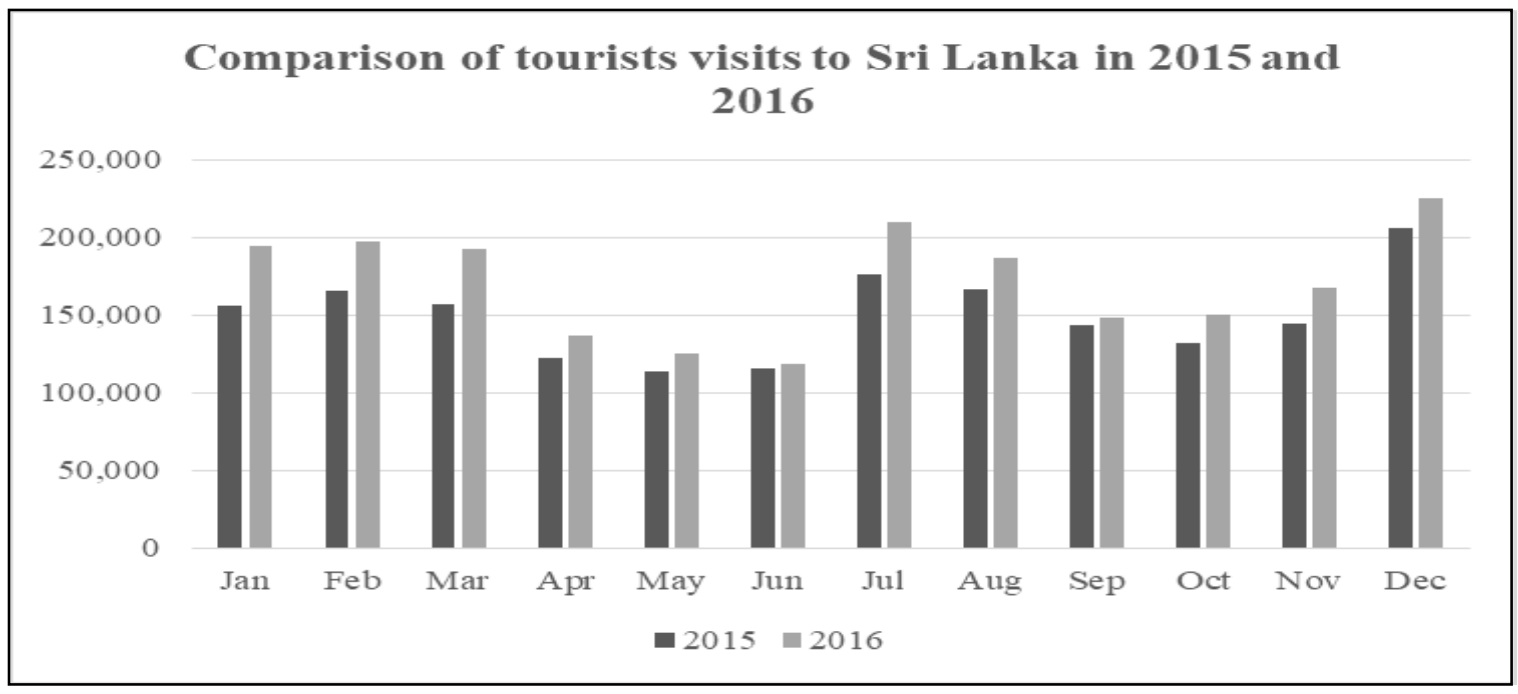

Source: Sri Lanka Tourism Development Authority (2016)

There are six areas representing key challenges for SMEs in the hotel industry. McAdam and Kelly (2002) have foreseen that the main challenges to growth in the SME hotel sector are niche players, limited resources, lack of skilled labour, market intelligence, lack of competitive benchmarking and long-term strategy. Jones and Hwang (2002) attributed small business failures to poor management competencies, including a lack of preparedness and a failure to control costs. Conversely, the individual skills and commitment of employees within the enterprise is seen as hugely significant to the success of the enterprise (Matlay, 1999). Jayawarna, MacPherson, and Wilson (2007) also noted the shortage of management skills and training provided within the SME sector. Rigby (2004) and Turok and Raco (2000) suggested that, unsurprisingly, adequate training will not occur within the SME sector without external intervention. Small and medium scale hotels are a vital segment in Sri Lanka's tourism industry. It is the fastest growing community in Sri Lanka's tourism industry at present (Association of Small and Medium Enterprises in Tourism to Promote Sustainability, 2013). However unlike the larger hotels, small hotels lack capabilities in the fields of marketing and customer service. Because of this reason, average occupancy in these hotels is around 30-40 per cent (Samaraweera, 2006). In addition, Trip Advisor reviews reveal that most negative comments about Sri Lankan small and medium hotels are about the poor management of those hotels (Epitom Consulting, n.d.). 


\section{Research Problem}

Hotel sector in Sri Lanka faces two major challenges. On one hand, the industry consists of a large number of providers, 906 lodging establishments with 20,794 rooms were registered by 2011 (International Finance Corporation [IFC], World Bank Group, 2013). Therefore, the authorities face difficulties in implementing standards and assuring the quality of services. On the other hand, the need of developing a dynamic service staff to deliver better quality services to tourists also poses a challenge. However, most hotels operate barely reaching the breakeven point. They lack the experience required to run a tourism business using modern management applications. The very nature of tourism demand renders them uncompetitive since they are unable to capitalize on the advantages that can be acquired from economies of scale. Therefore, it has become a difficulty to provide proper training to employees. Thus, it is required for them to formulate a proper tourism marketing strategy and a staff development strategy through which they can engage with lifetime customers (Wijesiri, 2010).

In this context, employee training is an important factor in a dynamic business environment to provide a better service to the customer and to gain a competitive advantage (Wijesiri, 2010). Tourism Development Authority of Sri Lanka and the Hotel School have proposed skill-training projects to improve the skill levels of those employed in the hotel industry. This would play a vital role in terms of providing sufficient training (Sri Lanka Tourism Development Authority, 2011). However, the proposed programmes are applied only to the development of registered hotels. Yet, to provide a good customer service well trained employees are required. Therefore, training is essential in providing good customer service and well trained staff knows what they need to practice and perform. Training in desired skills and knowledge can be considered an investment in an organization. Training also can be considered as a way to improve employees' satisfaction level concerning their personal and professional development (Dhar, 2015). Scott and Meyer (1991) have suggested that investment in employee training contributes significantly toward raising the productivity and performances of an organization. Although, it is widely reported that training is less likely to be received by both managers and non-managers in small and medium-sized enterprises (SMEs) than in larger firms (Curran, Blackburn. Kitching, \& North, 1996). Providing training encourages staff to create lifetime customers. This is an essential aspect in developing professional working staff in the hotel industry. However, the impact of professional training in small and medium hotels in Sri Lanka is not determined. Therefore, this study aims to identify the relationship between the professional training and the customer satisfaction in small and medium hotels in Sri Lanka.

This paper has three objectives that direct to accomplish main aim of this study. The first objective is to identify existing level of professional training and skills in small and medium scale 
hotels. The second objective is leading to determine what customers think of the professionalism of service in small and medium scale hotels. Finally, it is required to determine what areas of professional training required in order to increase customer satisfaction in small and medium scale hotels. Research questions were formed to cater to the above objectives; therefore, three questions were set to discuss under this study. First question is to understand the current level of professional training and skills in the staff of small and medium scale hotels. Second question is to understand the customers' perspective towards professional skills level of employees in small and medium scale hotels. The third and final question is to understand the areas of professional training required in order to increase customer satisfaction in small and medium scale hotels.

\section{Literature Review}

The hotel sector in Sri Lanka is very competitive at present and depends on customer satisfaction. Aspects such as cleanliness, security, personnel services, standard of service, appealing images, price, location, physical attractiveness, locations for relaxation and reputation are characteristics recognized by travellers to assess the quality of a hotel (Atkinson, 1988).

\section{Professional Training and Customer Satisfaction in the Hotel Sector}

Quality of service provided to clients is directly linked with the attraction of tourists to a hotel. Quality of service depends on the quality of employees. Quality means the knowledge, skills and thoughts which lead to the development of the hotel and its survival. Therefore, staff training is essential to increase productivity through quality service (Nickson, 2007). Professional training brings confidence, sound knowledge, skill development, experiences and positive attitudes to the employees. Finally professional training ensures that a quality service is provided to the customer and the hotel automatically increases its image through the quality service it provides. Providing training opportunities to the staff is an important development strategy of many successful hotels. Training and development is one of the key instruments in the hotel industry when practicing Human Resource Management and policies (Nickson, 2007).

Hospitality industry is heavily dependent on services provided to customers. In order to improve and maintain the quality of service, services provided by an organization should be able to meet the customer's demands to a satisfactory level. There should be a quality staff in order to provide good quality services to the customer. A quality staff would consist of active individuals with confidence, experience and knowledge. Especially in the modern world, the use of communication technology and information technology in tourism industry is rising rapidly. Hence, professional training is key to successfully facing competition in the hospitality industry. Training has a direct relationship with employee performance. Basically, training is a formal and 
systematic modification of behaviour through learning which occurs as a result of instruction, education, development and planned experiences (Armstrong, 2000). It is important to train employees effectively. Studies have proven that high cost but effective training can save money and time when compared with cheap training methods (Ginsberg, 1997). Therefore, training has acquired value for hotels (Partlow, 1996), since service quality reflects customer satisfaction.

\section{Service Quality and Customer Satisfaction in the Hotel Sector}

Many recent studies have suggested that emotions play a major role in perceived levels of service quality and customer satisfaction (Dube \& Menon, 1998). These researches link feelings of anger and frustration with increments in dissatisfaction and emotions such as happiness have been linked with increments in satisfaction, especially in building relationships. Service delivery was rated as satisfied by customers and many businesses in the past have been satisfied with meeting perceptions of customers, whereas nowadays named as customer satisfaction (Fisk, 2002). For small enterprises, establishing personal relationships with customers and employees can be a main source of competitive differentiation. The business dealings of small enterprise managers are often not based on contracts, but on personal relationships. This implies loyalty, personal service, understanding in difficult service encounter situations and potential personalization of services and products leading to competitive advantages which are difficult to imitate (Meissner, 1994; Morrison, Remington, \& Williams, 1999).

There is a relatively high proportion of large hotels achieving poor to satisfactory ratings from customers across the determinants identified by hotel management as critical to service quality. This is a serious issue in a highly competitive market (Briggs, Sutherland, \& Drummond, 2006). However, many employers are still reluctant to provide necessary support to staff despite the public policy discussions in a number of countries regarding the improvements that can be gained through training and development strategies (Noble, 1997). This commitment, or lack thereof, appears to be reciprocated. Thus, it would appear that there is a connection between organizations developing training and development policies, which in turn lead to increased service standards through committed and satisfied staff, and ultimately increased productivity (Frabetta, 2000; Hays, 1999). There is also a growing recognition that training has a significant role in achieving competitive advantage (Frabetta, 2000). It allows the organization to provide a better quality of service, thus enabling them to develop a competitive niche market, which should in turn encourage repeat customers by developing a higher level of customer loyalty through good service quality provision (Schlesinger \& Heskett, 1991). Therefore, the significance of an appropriate training profile for all businesses within the accommodation sector is of considerable importance for both process quality and output quality by which that organization is evaluated. 


\section{Training in the Hospitality Industry}

Following types of trainings are available in the hospitality industries which are very effective to increase quality of the hospitality industry.

1. Communication. Without the means, the capacity and the will to communicate, what we know as business, government, and community activities not be. But it is not enough for people to talk to others. They need to know how to talk with others, too (Lee, 1952). Communication training increases the diversity of today's workforce with a wide variety of languages and customs. Communication is a managerial responsibility.

2. Computer skill. Computer skills have become compulsory to employees in the modern world. These skills are a necessity to conduct administrative and office tasks within the hospitality industry.

3. Customer service. Customer satisfaction with a purchase depends on the product's performance relative to a buyer's expectations. A customer might experience various degrees of satisfaction. If the product performance falls short of expectations, the customer is dissatisfied. If performance matches expectations, the customer is satisfied. If performance exceeds expectations, the customer is highly satisfied or delighted (Kotler \& Armstrong, 1996). Hospitality industry depends on services provided to customers. Increased competition in today's global market makes it is critical that employees understand and meet needs and wants of customers.

4. Ethics. Ethics can be defined broadly and simply as the study of how our decisions affect other people. It is also the study of people's right and duties, the moral rules that people apply in making decisions and the nature of the relationship among people (Kotler \& Armstrong, 1996). Society in the modern world has increasing expectations about corporate social responsibility and encourages the creation of a workforce that can bring a wide variety of values to the organization.

5. Diversity. Diversity training focuses on the employee to help them understand different perspectives and views of people and also includes techniques to value diversity.

6. Human resource management. These are the management functions that deal with recruitment, placement, training, and development of an organization's members (Kotler \& Armstrong, 1996). Human resource management training ensures smooth interactions among employees and also creates a suitable path to the organization to achieve its goals.

7. Safety. Safety training is compulsory for any organization to minimize damage and evacuate people in the event of manmade or natural disaster. During day-to-day hotel operations, it is possible to meet with numerous accidents. Proper safety training helps to prevent or minimize damage or harm caused by such accidents. 
8. Quality initiatives. Training in quality assurance guides employees towards the provision of quality product and services through training courses on quality management, quality circle as well as basic training on quality.

9. Sexual harassment. Training on sexual harassment focuses on protecting clients from sexual harassments through identifying and preventing inappropriate behaviour by employees.

10. Other professional training. Other professional training includes steward courses, cookery courses, guest relation courses, numerous management courses, barman courses and housekeeping courses etc.

Numerous benefits can be gained by individuals and organizations through a well-planned and effectively executed training program. There are benefits such as increased employee motivation, increased efficiency in processes, increased profits (Financial gains), increased job satisfaction, increased capability to adopt new technology and new methods, increased innovation and product development, enhanced hotel image, reduced employee turnover, risk management, increased customer loyalty, significantly increased revenue, reduced losses due to billing errors and reduced cost (Nickson, 2007). However, the management functions of strategy development, marketing and quality management and technology adaptation are often the core deficiencies in small hospitality businesses (Buhalis \& Main, 1998).

\section{Definitions of Training}

Various researchers have presented different definitions to explain the meaning of training. While Sloman (2005) defined training as an instructor-led, content-based intervention leading to desired changes in behaviour, Sommerville (2007) identified training as a process that provides employees with knowledge and skills required to operate within the system and standards set by management. In 2006, Karla and Batia defined training as a process of learning a sequence of programmed behaviour. It is the application of knowledge which gives people awareness and procedural guidance regarding behaviour. It helps to make positive changes in knowledge, skills, and attitudes of employees. Professional training encompasses all types of facilitated learning opportunities ranging from university degrees to formal coursework, conferences and informal learning opportunities involving practical application.

Based on various definitions, Ahammad (2013) has developed the training and development cycle. Initial stage of the training cycle is the execution of the process of identifying and finding out training needs. In this stage, the focus is to identify training needs, i.e., who needs what training (target audience) to meet goals of the organization through achieving the expected outcome and impact. Second stage covers the planning, design and development of training. Its aim is to meet the goals of the organization with final outcomes through a methodical and 
consistent approach. Third stage ensures that the delivery of training is effective and provides opportunities to the target audience to learn. Fourth stage ensures all the outcomes are applied and reinforced in practice within the hotel environment. In this stage, action to monitor the individual's development and review their progress is facilitated. In the final stage, it deals with the collection, analysis and presentation of information to establish the performance of trainees through what they gained from the training. This stage helps to evaluate the training programme in order to re-adjust or develop it according to the goals of the organization (Ahammad, 2013). Training programmes can be designed in accordance with the above stages. However, the organization has the freedom to select a suitable training method which is more effective in training their employees.

\section{Methods of Training}

The training needs of such employees are not always easy to determine, and when they can be, the individuals involved may resent being asked to change their established ways of doing their jobs. The most widely used methods of training by organizations are classified into two categories. They are, on the job training and off the job training.

On the job training. This type of training is given by the superior in a relatively short period of time at the work place. This is a time consuming and cheaper training method. In contrast to vestibule or off the job training, new employees are assigned to on the job training in a specific job at a machine or a workplace in the shop, office, or laboratory. They are then instructed by an experienced employee, a special instructor, or the first level supervisor. However, this type of training may be most effective for rapid training of large number of unskilled and semiskilled workers (Pigors \& Myers, 1981). There are four major formal on the job development methods.

Coaching - Coaching is learning by doing. In this method, the superior guides his subordinates and gives job related guidance and instructions. The supervisor can identify the weaknesses of the trainees and can correct them there itself (Stoner, Freeman, \& Gilbert, 2003).

Job rotation - In this system, the trainee moves from one job to another and employees are trained to perform all types of duties. This is a good training method for the survival of the organization and its smooth operation in emergency situations (Stoner et al., 2003).

Training positions - This is the third method of developing managers. Trainees are given staff posts under a manager, often with the title of "assistant to". Such assignments give trainees the chance to work with and model themselves after outstanding managers who might otherwise have little contact with them (Stoner et al., 2003). 
Planned work activities - This activity provides trainees important work assignments to develop their experience and ability. Trainees may be asked to create a plan of how organizations operate and also improve their human relations skills (Stoner et al., 2003).

Off the job training. This type of training is given outside the actual work place. "Off the job development techniques remove individuals from the stresses and ongoing demands of the work place, enabling them to focus fully on the learning experience. In addition, they provide opportunities for meeting people from other departments or organizations. Thus, employees are exposed to useful new ideas and experience while they make potentially useful contacts." (Stoner et al., 2003).

Lectures/Conferences - This is a much adopted method to educate and disseminate instructions, information, rules and procedures. The cost of training in this method is low due to the ability to disseminate knowledge and information to a large number of trainees at once. Almost every management development programme includes some form of classroom instruction in which a specialist from inside or outside the organization teaches trainees a particular subject. Classroom instructions are often supplemented with case studies, role playing, and business games or simulations (Stoner et al., 2003).

Role play - This method delivers the message and knowledge through acting a drama written to match the particular situation (Stoner et al., 2003).

Management games - Trainees are divided into two groups which represent the management and the competitive management. The game is applied to a model of a business situation and creates real life situations in which decisions must be made. Finally feedback on evaluated decisions are given to the group (Stoner et al., 2003).

Simulation exercises - Any training activity that explicitly places the training in an artificial environment that closely mirrors actual working condition can be considering a training simulation (Pigors \& Myers, 1981).

Cases - Taking a particular current problem or incident, trainees are asked to find and analyze the problem, evaluate courses of action and decide what course of action would be most satisfactory (Pigors \& Myers, 1981).

Films - Provide information and explicitly demonstrates skills that are not easily presented by other techniques (Stoner et al., 2003).

Experiential exercise - This is basically a short and structured learning experience where individuals learn by doing something (Pigors \& Myers, 1981).

Vestibule training -Employees learn their job on the equipment they will be using, but the training is conducted away from the actual framework. This type of training allows employees to get a full feel for engaging in the task without being affected by real pressure of the work. In some cases, an attempt is made to duplicate the work as closely as possible in vestibule training so that it permits more emphasis on teaching the best method. 
Furthermore trainees have an opportunity to get accustomed to work routines and recover from their initial nervousness before going on to engage in the actual job (Pigors \& Myers, 1981).

As explained, the staff of small and medium hotels can be trained by using one or more methods. However, it is upon the management to select effective training methods to use on their staff. Different methods can be implemented at once or one after the other, based on the nature of the staff. For an example, stewards can be trained on the job since it is more effective than off the job training. Thus, each new member of staff is required a proper orientation before they commence work.

\section{Employee Professionalism and Customer Satisfaction}

The relationship between employee professionalism and customer satisfaction has attracted much research in recent years. Employee professionalism is the overall evaluation of the human resource of the hotel and the customer satisfaction is concerned with the overall evaluation of the experience at the hotel. Management must rather view employees as valuable contributors whose opinions and perceptions are important sources of knowledge (Rousseau \& McLean Parks, 1992). In this sense, employees are similar to customers; their satisfaction and retention are instrumental (Ronald, Stewart, Miller, \& Pielack, 1996). Therefore, training and development is another area that can benefit from the metaphor of employee as customer (Lawler, 1992).

High satisfaction has been linked to retention of both customers and employees. Customers who are satisfied have higher repurchase intentions, which in turn translate into repeat purchases (Anderson \& Sullivan, 1993). Employees who are satisfied have higher intentions of staying with an organization, which results in decreased turnover (Mobley, Griffeth, Hand \& Meglino, 1979).

This review suggests that professional training is an important concept which will have an influence on customers when they receive quality service. However, definitions and determinants of training and delivery of service quality remain essential. The combination of characteristics and complexities identified in the review led to create the following conceptual model of this study.

As discussed in the literature review the following variables were identified to design the conceptual framework of this study. Customer satisfaction considered as the dependent variable on the professional training provided by hotels. Therefore, communication skills, computer skills, working diversity, ethics, disciplines and safety measures were considered as sub-variables. These variables and their relationship have located to treat the objectives in this study. 


\section{Methods}

Aim of this research is to analyse how professional training supports to improve customer satisfaction in small and medium scale hotels. Although there are 314 hotels registered in Sri Lanka Tourism Development Authority, the selection of SME hotels was based on the convenience sampling method in consideration of the availability of time and funds. Using simple random sampling, 10 hotels were selected to gather data. All of these hotels are located in coastal areas. The population of this study comprises of all 53 employees including management staff of these hotels. They have been selected to the sample one. A questionnaire given to employees contained 17 questions on personnel information and research information to identify the existing level of professional training and the future training requirement. During the time of this study was conducted, 50 local and foreign customers were selected as sample two to gather information on customer satisfaction regarding service delivery. Data on local and foreign customers was collected via a questionnaire with the assistance of the managerial staff. The response rate of sample two is 60 per cent as only 30 customers were able to give the feedback. This questionnaire was to measure the quality of service and repetition of customers. The univariate analysis was used with the application of correlation analysis.

\section{Data Analysis}

Primary data collection was divided into two sections. Sample one was to provide an opportunity to employees to evaluate themselves. The second sample was to study the consumer opinion on the delivery of service they received and the satisfaction.

\section{Existing Level of Professional Training - Employees' Perspective}

This section provides an analysis of information on training and support provided to staff by the management of small and medium hotels. The existing level of professional skills and development needs are necessary to this survey.

The findings have identified the levels of training provided to employees by their organizations. This result shows that only 25 per cent of the employees have followed a professional course relevant to the hotel field. 75 per cent out of the total employees have not undergone even one course relevant to the hotel field. Majority of employees have joined the hotel sector without professional education. However, this result reflects the lack of awareness of management to identify training needs.

Orientation and professional training programmes offered by the hotel is one of the important factors studied in the survey. Only 19 per cent of the employees have undergone a hotel course given by respective hotel management. Remaining 81 per cent of the employees were not 
provided with any professional development programme by the respective hotel managements. As Table 1 shows, the high standard deviation reflects the failure of hotel management to identify what is required in order to provide a quality service to customers.

Table 1: Statistical Table on Employees' Perspective

\begin{tabular}{lrrr}
\hline & $\begin{array}{r}\text { Training support } \\
\text { provided by the hotel } \\
\text { to the employees }\end{array}$ & $\begin{array}{r}\text { English language } \\
\text { skills of employees }\end{array}$ & $\begin{array}{r}\text { Computer skills of } \\
\text { employees as a } \\
\text { percentage }\end{array}$ \\
\hline Mean & 50 & 20 & 20 \\
Standard Error & 31 & 10.51189802 & 10.01498877 \\
Median & 50 & 5 & 13 \\
Mode & No & Average & Very weak \\
Standard Deviation & 43.84062043 & 23.50531855 & 22.39419568 \\
Sample Variance & 1922 & 552.5 & 501.5 \\
Kurtosis & - & -0.219512295 & -0.673852818 \\
Skewness & - & 1.155028859 & 0.871495942 \\
Range & 62 & 53 & 53 \\
Minimum & 19 & 3 & 0 \\
Maximum & 81 & 56 & 53 \\
Sum & 100 & 100 & 100 \\
Count & 2 & 5 & 5 \\
\hline
\end{tabular}

English language has a significant role in the operation of a hotel where both foreign and local guests visit. Communication is essential in order to provide a quality service that both parties can accommodate. Skewness shows a right tailed data distribution and kurtosis shows a light distribution. This results a moderate distribution of data. Level of English language skill of the employee was identified in the study. The standard deviation presents that the majority of employees have a manageable level of knowledge in the English language. Employees had not been provided with special training on languages by the hotel. However, their level of language knowledge appears to have been improved with the time and experience.

The level of computer skills of employees is shown in statistical Table 1. The standard deviation reflects that more than 50 per cent of employees have a training requirement in computing and related applications. However, there is a well behaved skewness, the kurtosis has a light data distribution. This indicates a training requirement in computing. Foreign customers 
use online reservation options and tend to work with applications all the time. Therefore, employees must be familiar with computing and applications in order to provide a quality service.

\section{Existing Level of Professional Training - Customers' Perspective}

With the objective of measuring the quality of service of Small and Medium scale hotels, one questionnaire was distributed among 30 customers using the convenient sampling method. 16 local customers and 14 foreign customers participated in this survey aimed at measuring the quality of service and level of satisfaction.

In the evaluation, the English language fluency of many hotel staff was marked as poor by the customers. As shown in Table 2 the data set is a normal distribution as the skewness is zero while the kurtosis shows a heavy tailed distribution. However, some customers have rated the language skills as satisfactory which show in the less than 50 per cent standard deviation which emphasizing that the language fluency of the staff is manageable.

Table 2: Statistical Table on Customers' Perspective

\begin{tabular}{lrrrrr}
\hline & $\begin{array}{c}\text { English } \\
\text { language } \\
\text { skills of } \\
\text { employees }\end{array}$ & $\begin{array}{c}\text { Diversity of } \\
\text { employes }\end{array}$ & $\begin{array}{c}\text { Behaviour / } \\
\text { discipline of } \\
\text { employees }\end{array}$ & $\begin{array}{c}\text { Attitudes of the } \\
\text { employees }\end{array}$ & $\begin{array}{c}\text { Safety } \\
\text { provided to } \\
\text { customers }\end{array}$ \\
\hline Mean & 20 & 20 & 20 & 20 & 20 \\
Standard Error & 6.519202 & 6.395310782 & 10.95445115 & 11.24277546 & 9.94484791 \\
Median & 20 & 20 & 20 & 12 & 13 \\
Mode & Poor & Satisfactory & Very satisfactory & Very satisfactory & Satisfactory \\
Standard Deviation & 14.57738 & 14.30034965 & 24.49489743 & 25.13961018 & 22.237356 \\
Sample Variance & 212.5 & 204.5 & 600 & 632 & 494.5 \\
Kurtosis & 0.892734 & 1.569586504 & 2 & 1.038615606 & -2.8173999 \\
Skewness & 0 & 0 & 1.360827635 & 1.258793171 & 0.42968715 \\
Range & 40 & 40 & 60 & 60 & 47 \\
Minimum & 0 & 0 & 0 & 0 & 0 \\
Maximum & 40 & 40 & 60 & 60 & 47 \\
Sum & 100 & 100 & 100 & 100 & 100 \\
Count & 5 & 5 & 5 & 5 & 5 \\
\hline
\end{tabular}

Table 2 above shows the workforce diversity of employees of small and medium hotels in Sri Lanka. The applied workforce diversity represents similarities and differences in terms of age, cultural background, physical abilities and disabilities, religion and gender balance. This was 
explained to customers before the survey. Applying that, the symmetric distribution is normal as the skewness in zero while the kurtosis is heavy tailed. Majority of customers have stated that the workforce diversity is satisfactory or ordinary among the workforce of hotels.

This survey was aimed at studying the professionalism of staff in their treatment of customers. The customers were asked to evaluate discipline, dress code and behaviour of the staff of hotels. The right skewed distribution has a heavy tailed kurtosis. More than 50 per cent standard deviation shows the majority of the customers are satisfied with discipline, dress code and behaviour of the staff. This reflects that even if there is an insufficiency in training, the employees follow the rules and regulations stipulated by the hotel management.

The data distribution regarding employee attitudes is right skewed and heavy tailed since the kurtosis is 1.03 . The standard deviation is more than 50 per cent which indicates that the majority of the customers have stated that they experienced positive attitudes and a mind-set from the staff during their stay in hotels. They were facilitated and supported by staff at anytime they requested their assistance. The overall result has a positive outcome as customers rated the attitude and positive mind-set of employees as satisfactory.

In terms of safety initiatives, 47 per cent of the customers were very satisfied with safety initiatives and measures provided by hotels during their stay. The standard deviation is more than 50 per cent and it indicates the requirement of implementing more safety initiatives in small and medium hotels sector. The data distribution is close to normal while the kurtosis is light tailed. Lifesaving, medical and health care, security and privacy are the main consideration in this measurement.

\section{Customer Satisfaction, Recommending to Others and Future Intentions}

Main objective of this survey is to measure customer satisfaction based on the service provided by selected hotels in Sri Lanka. 15 per cent of the total sample population were very satisfied with the service provided by small and medium hotels based on the experience they received and 23 per cent of the customers have stated that their satisfaction is ordinary. Quality service, language fluency, attitudes, disciplines and safety initiatives provided by staff were considered as parameters to measure overall customer satisfaction.

This survey looked at the way a customer would respond to another customer seeking information on hotels in Sri Lanka. It was revealed that only 40 per cent of the customers will recommend these places to another customer. 60 per cent of the customers will not recommend 
the hotels they stayed in, due to bad experience they received. The service, support from the management and infrastructure facilities were the parameters to measure this variable.

Results also revealed that there are more than 67 per cent of the customers would not repeat their visits to these hotels due to bad experiences they had. Less than 33 per cent of the customers have stated that they will come back and experience the service of those hotels.

\section{Correlations between Key Variables}

Relationship between customer satisfaction and quality of service is a positive correlation as shown in Figure 2. It could be said that customer satisfaction is positively affected by the increase of quality of service. In other words, these two variables are closely interrelated and an increase in one will make a considerable change in the other. Therefore, quality of service can make an impact on customer satisfaction.

Figure 2: Correlation between Customer Satisfaction and Quality of Service

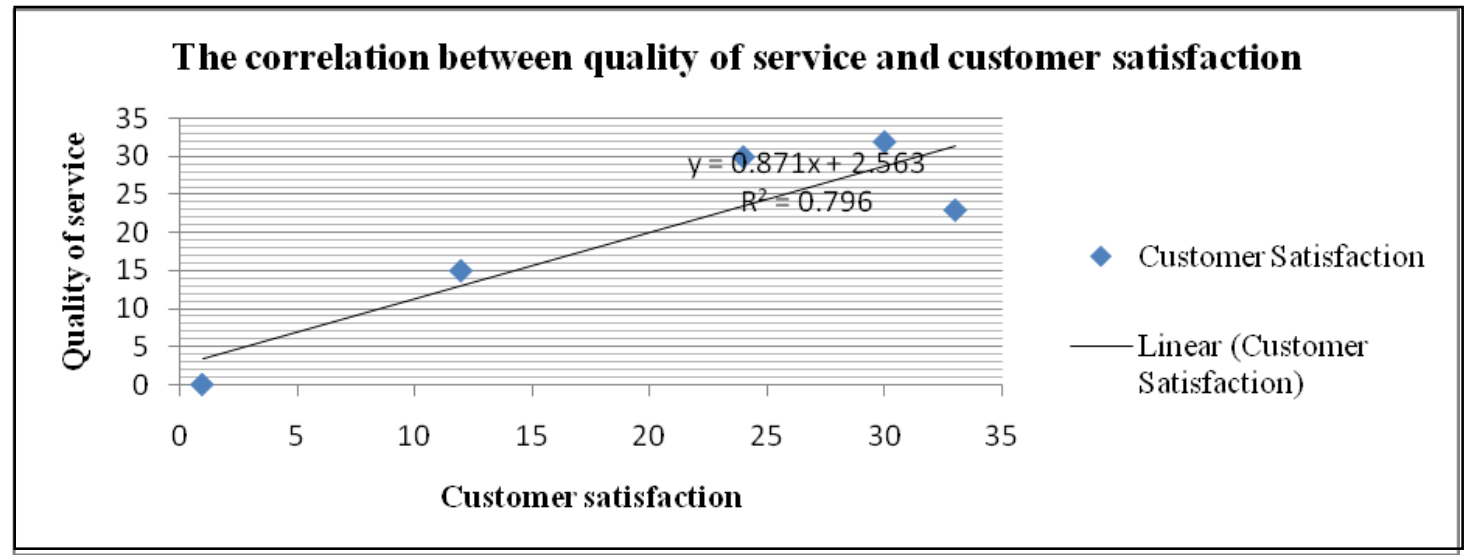

Relationship between quality of service and employee training is a positive correlation as shown in Figure 3. It could be said that quality of service is positively increased by an increase of employee training. In other words, these two variables are closely interrelated and an increase in one will make a considerable change in the other. Therefore, employee training can make an impact on quality of service.

Relationship between customer satisfaction and employee training is a positive correlation as shown in Figure 4. It could be said that customer satisfaction is positively increased by an increase of employee training. In other words, these two variables are closely interrelated and an increase in one will make a considerable change in the other. Therefore, employee training can make an impact on customer satisfaction. 
Figure 3: Correlation between Quality of Service and Employee Training

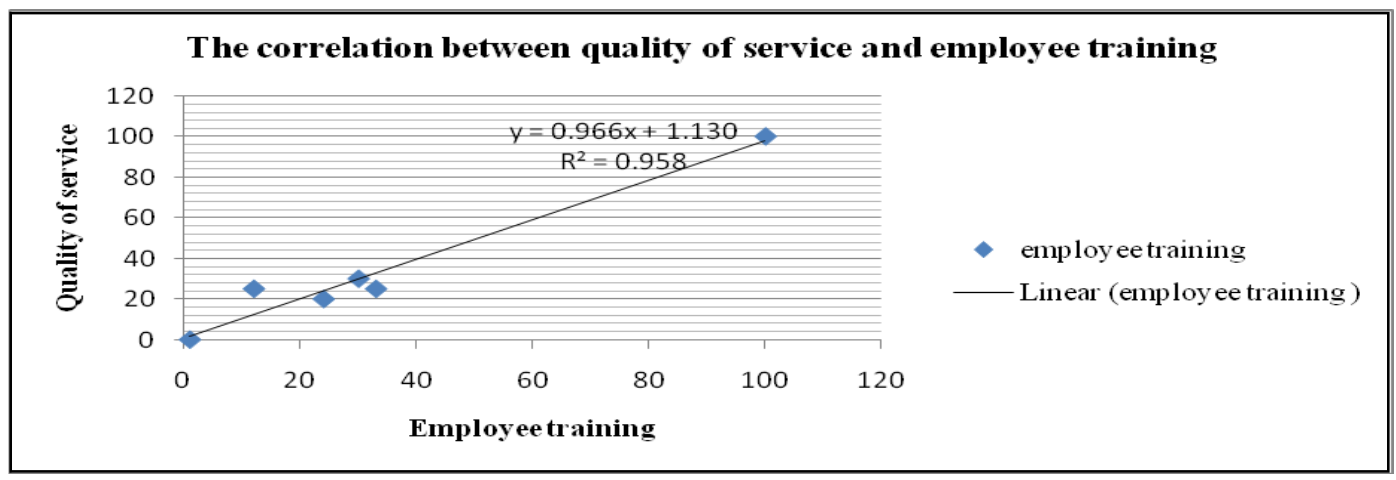

Figure 4: Correlation between Customer Satisfaction and Employee Training

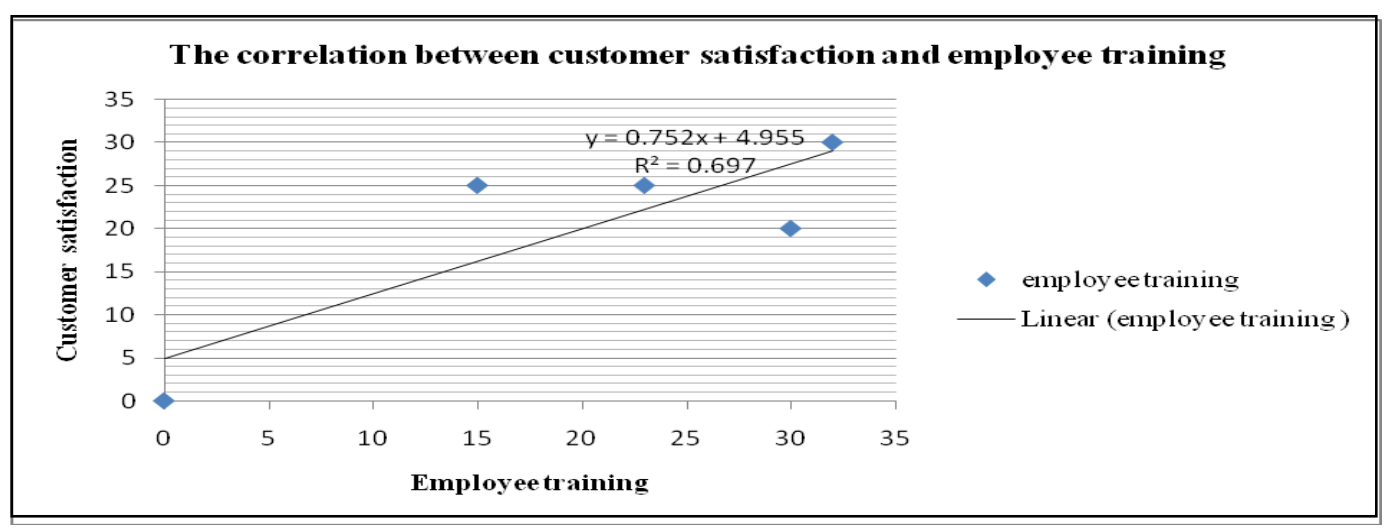

\section{Improving Professional Training}

The need for training programmes and courses from the point of view of employees also tested. More than 95 per cent of employees who occupied in these hotels have an opinion that they need professional training to provide better service and create satisfied customers. Employees have further emphasized that training is required to meet industry standards within a competitive environment. According to the findings, most employees require hotel courses that will provide them a better foundation in their career and global standards of meeting customer requirements. Secondly, they prefer to receive English language training as it is a requirement to build strong communication with customers. Employees who were assigned duties in the reception and marketing sections have mentioned that there is a need of improving their computing and application skills. This survey also looked at suitable training methods that employees would prefer to undergo. More than 50 per cent of employees would prefer to participate in practical workshops which provide solutions to many practical problems in hotel services. As per their view, training would be more effective if they are facilitated by foreign 
lecturers and local authorities. Some employees have mentioned that outbound training programmes also are effective in improving professional skills of hotel staff.

This survey also looked at the customer's point of view on future training requirement. The majority ( 87 per cent) of the customers who participated in this survey stated that employees need further professional training to increase the quality of service while 13 per cent of the total sample population believes the employees have enough training to offer a quality service.

\section{Discussion}

This survey was carried out to identify training needs and requirement of professional training to improve customer satisfaction in small and medium scale hotels in Sri Lanka. The survey was based on collecting information on the employees' views and the customers' views. As far as professional training of employees is concerned, 75 per cent of the total employees have not undergone any professional training relevant to the hotel field. Only 25 per cent of the employees are equipped with professional training. Further, the respective hotels in the sector have provided professional training only to 10 per cent of the total employees. Programmes to impart English language skills and computer skills also have not been provided adequately to the staff. Further, 98 per cent of employees have agreed that professional training is necessity to increase quality of service. Past studies have shown that giving employees an opportunity to learn, develops a higher level of commitment among employees, compared to job security, monetary benefits, and job satisfaction (McNeese-Smith, 2001). However, it is revealed that most employees prefer to follow practical workshop type trainings which provide solutions to practical problems. 87 per cent of employees believe that professional training is effective to create satisfied customers and also support the development of career skills. Some past research supportively discussed that a training program that is effective may also lead to employees forming an opinion that their organization demonstrates a willingness to invest in them showing that the organization cares for them. This encourages a higher level of commitment among employees toward their organization (Brunetto, Farr-Wharton, \& Shacklock, 2012).

Quality of service, discipline of employees, attire, attitudes of employees, quality initiatives taken by employees and safety measures provided to customers appear to be satisfactory. 47 per cent of customers are 'highly satisfied' with the service provided by small and medium scale hotels while 40 per cent of customers are 'satisfied'. Many customers would like to recommend these hotels to other potential customers. High satisfaction has been linked to retention of both customers and employees. Previous research has proven that customers who are satisfied have higher repurchase intentions, which in turn translate into repeat purchases (Anderson \& Sullivan, 
1993; Rust \& Zahorik, 1993). This reflects that the majority of them are willing to come back and experience the same hotel in near future.

Customers have clearly stated that there is a training need in hotel staff, especially a need to improve language, computing skills and professional skills. Customers also have clearly pointed out the importance of professional training to increase quality of services provided by small and medium scale hotels in Sri Lanka. According to Rust, Stewart, Miller and Pielack (1996), the importance of satisfying needs and wants remains constant, meaning that the management of employees is often similar to the management of customers. Trained and skilled employees can satisfy and retain customers for a long period of time. Some skills like computing are not required by all employees. Computer training is required by those engaged in duties such at the reception, in the marketing division and reservations division. 98 per cent of employees believe that professional training is a necessity for their career development and 87 per cent of customers believe that employees need further professional training to increase the quality of service in these hotels. According to the view of employees, more hotel courses (related to the respective field), English language courses and computer courses are required to achieve higher customer satisfaction. Finally, according to the point of view of customers, proper training would develop a better employee that would lead to the creation of repeat customers who would not opt for a competitor hotel. This survey proves that a trained and satisfied employee can satisfy a customer. This result supports the argument of Schneider and Bowen (1985), where they say that organizations with satisfied employees have satisfied customers and that performance of such organizations show that satisfied employees lead to higher levels of customer retention.

\section{Conclusions and Managerial Implications}

This study empirically discussed important aspects related to professional training that would lead to creating satisfied customers in small and medium hotels in Sri Lanka. Employees are required to train professionally in order to provide a superior service to customers. The results showed that there is a need of training in the small and medium hotel sector in Sri Lanka. A trained staff is capable of satisfying a customer and building long term relationship. The satisfied customer retains with the service and brings repeat businesses that have proved by this study as only 33 per cent of customers have stated that they repeat the same hotel in future when the overall satisfaction of them stated as 47 per cent. Therefore, to earn more customers, the hotels must focus to build relationships with customers. The surface where the hotel and customer meets is employees. Thus, a professionally trained employee can serve a customer well and is able to build long-term relationships. 
Finally, based on the findings of this study, it is revealed that the relationship between the professional training and creating satisfied customers in small and medium scale hotels is positively correlated each other. Both customers and the employees believe that when the professional training is high, the quality of service at these hotels also go high. Therefore, the level of customer satisfaction will increase.

The hotel sector in Sri Lanka has been identified as one of the major income sources to be developed in order to reach economic development goals. The government has focused its attention to develop this sector by increasing infrastructure and inviting reputed foreign hotel chains to open businesses in Sri Lanka. Meantime, as this study discussed there are new beginners in the local small and medium scale hotel industry. Local and foreign customers are highly attracted to such hotels too. Therefore, the management needs a careful supervision of meeting and fulfilling customer satisfaction. Quality of service is one aspect which attracts more customers locally and internationally. In order to establish such an environment, special attention should be paid to the performance of employees. Success of an organization depends on the performance of its employees. Training is a planned process to achieve effectiveness of performances and also to deliver a quality service. Success of training not only depends on employees but it also depends on the effort that management makes to provide effective training programmes. The management of small and medium hotels could provide efficient professional training to employees and increase quality of service delivered to satisfy customers. Good quality service keeps the customer highly satisfied.

The results of this study indicate the requirement of enhancing customer service in small and medium scale hotels in Sri Lanka. This study has discussed only one aspect relating to the enhancement of customer service which is employee training. Training on language, hospitality etiquette, disciplines, attire and attention on safety are essential where employee training is required. This study also proved that a well trained staff is capable of increasing customer's satisfaction and retaining customers for future business. Combined training methods are cost effective in this industry such as off the job training and on the job training. Conducting training seminars and organizing training conferences are also very effective for SME hotels when the finances become a constraint. It is also important to receive support from the government and other official authorities such as Sri Lanka Tourist Board, Sri Lanka Tourism Development Authority and National Enterprise Development Authority.

\section{Limitations of the Study and Directions for Further Research}

This study has covered only the areas of professional training requirement and the relationship between customer satisfaction and employee professionalism in small and medium 
hotels in Sri Lanka. Professional training can improve the quality of service and how quality of service can increase the customer satisfaction is the next step of this study. However, the quality has different dimensions which were not discussed in this study. The relationship between training and relationship marketing is another aspect which has not been covered by this research. The factors affecting the customer satisfaction can be varied and depended on many reasons in small and medium hotels in Sri Lanka. However, this has not been covered by this study. There are 314 registered small and medium hotels in Sri Lanka and some non-registered hotels also operate. However, the variations between registered and non-registered small and medium hotels have not been studied through this research. These are areas that can be further explored in future research

Further, this study has covered only selected small and medium hotels in Sri Lanka which were registered under the Sri Lanka Tourism Board. However, there are 906 (IFC - World Bank Group, 2013) registered small, medium and large hotels in Sri Lanka and some non-registered hotels. Thus, the variations between registered and non-registered small and medium hotels have not been studied in this research. Therefore this research directs an area to observe the professional training requirement, existing level of training and differences of services in all registered hotels and non-registered hotels in this industry. Moreover, training is only one factor which results in increasing the customer satisfaction. However, there are some other factors such as quality service, infrastructure facilities, technology and credibility which play a major role in service sector. These factors and their influence on customer satisfaction in small and medium scale hotels in Sri Lanka is another direction of future research.

\section{References}

Ahammed, S. (2013). Importance of training in hotel industry: A case study of Hilton Hotel, Cyprus (Masters Dissertation, Sordertons University) Retrieved from: http://sh.divaportal.org/smash/get/diva2:651957/FULLTEXT01.pdf.

Alsaqre, O. Z. E. (2011). Investigating the effects of tangible and intangible factors on customers' perceived service quality and loyalty in hotel industry in al-ladhiqiyah, Syria. Retrieved from http://cf.cdn.unwto.org/sites/all/files/alsaqre_research.pdf.

Anderson, E.W., \& Sullivan, M. W. (1993). The antecedents and consequences of customer satisfaction for firms. Marketing Science, 12(2), 125-143.

Armstrong, M. (2000). A handbook of human resource management practice (8th ed.). London: Kogan page limited.

Association of Small and Medium Enterprises in Tourism to Promote Sustainability (2013). The luxury Sri Lanka. Retrieved from http://www.theluxurysrilanka.com/association-of-smalland-medium-enterprises-in-tourism-to-promote-the-sustainable-tourism-developmentproject-in-sri-lanka/. 
Atkinson, A. (1988). Answering the eternal question: What does the customer want?. The Cornell Hotel and Restaurant Administration Quarterly, 29(2), 12-14.

Baker, T., \& Collier, D. A. (2005). The economic payout model for service guarantees. Decision Sciences, 36(2), 197-220.

Briggs, S., Sutherland, J., \& Drummond, S. (2006). Are hotels serving quality? An exploratory study of service quality in the Scottish hotel sector. Tourism Management. 28(4), 1006-1019.

Brunetto, Y., Farr-Wharton, R., \& Shacklock, K. (2012). Communication, training, well-being, and commitment across nurse generations. Nursing Outlook, 60(1), 7-15.

Buhalis, D., \& Main, H. (1998). Information technology in small and medium hospitality enterprises: Strategic analysis and critical factors. International Journal of Contemporary Hospitality Management, 10(5), 198-202.

Curran, J., Blackburn, R.A., Kitching, J., \& North, J. (1996). Establishing small firms' training practices, needs, difficulties and use of industry training organisations. London: Department for Education and Employment.

Dhar, R. L. (2015). Service quality and the training of employees: The mediating role of organizational commitment. Tourism Management. 46, 419-430.

Dube, L, \& Menon, K. (1998). Managing emotions. Marketing Health Services, 18(3), 34-43.

Epitom Consulting. (n.d). Marketing solutions for hotels in Sri Lanka. Retrieved from http://www.epitom.org/marketing-solutions-for-hotels-in-sri-lanka/.

Fisk, R. (2002, November). Service Excellent. Presentation at the first international symposium on Service Engineering and Management. Stuttgart.

Frabetta, D. (2000). Investing in the future. Hotel and Motel Management, 215(9), 4.

Ginsberg, L. (1997). Training for the long haul. Computer Shopper, 17, 4.

Hays, S. (1999, January 1). Exceptional customer service takes the 'Ritz' touch. Workforce. Retrieved from http://www.workforce.com/1999/01/01/exceptional-customer-service-takesthe-ritz-touch/

International Finance Corporation, World Bank Group. (2013). Ensuring sustainability in Sri Lanka's growing hotel industry. Retrieved from https://www.ifc.org/wps/wcm/ connect/30f331004fddd89eb9d8ff23ff966f85/Mapping+Report+++Ensuring+Sustainability+i n+Sri+Lanka's+Hotel+Industry.pdf?MOD=AJPERES

Jayawarna, D., Macpherson, A. \& Wilson, A. (2007). Training commitment and performance in manufacturing SMEs incidence, intensity and approaches. Journal of Small Business and Enterprise Development, 14(2), 321-328. doi.org/10.1108/14626000710746736

Jones, P., \& Hwang, L. J. J. (2002). Improving business performance in service SMEs: Modelling 'Best Practice'. Paper presented at $25^{\text {th }}$ ISBA National Small Firms Conference: Competing Perspectives of Small Business and Entrepreneurship.

Karla. R., \& Bhatia, M. (2008). Training concepts and methods. School of Management, Ansal Institute of Technology. Retrieved from: http://www.indianmba.com/faculty_column/ Fc797/fc797.html. 
Kotler, P., \& Armstrong, G. (1996), Principles of marketing ( $7^{\text {th }}$ ed.). New Jersey: Prentice-Hall International.

Lawler, E.E. III. (1992). The Ultimate advantage: Creating the high-involvement organization. San Francisco: Jossey-Bass.

Lee, I. J. (1952). How to talk with people, a program for preventing troubles that come when people talk together. Retrieved from http://communication.ucsd.edu/_files/Lee_How-to-Talkwith-People_1.pdfMatlay, H. (1999). Vocational education training and organisational change: A small business perspective. Strategic Change, 8(5), 277-289.

McAdam, R., \& Kelly, M. (2002). A business excellence approach to generic benchmarking in SMEs. Benchmarking: An International Journal, 9(1), 7-27.

McNeese-Smith, D. K. (2001). A nursing shortage: Building organizational commitment among nurses. Journal of Healthcare Management, 46(3), 173-187.

Meissner, H. G. (1994). Marketing for mittelta companies family business. In H. H. Hinterhuber \& O. Reichenau, \& M. Stumpf (Eds.), The mittelsta companies the family business: The integration of both subsystems family and business in the '90s (pp. 171-202). Frankfurt: Peter Lang.

Mobley, W. H., Griffeth, R. W., Hand, H. H., \& Meglino, B. M. (1979). Review and conceptual analysis of the employee turnover process. Psychological Bulletin, 86(3), 493-552.

Morrison, A., Rimmington, M., \& Williams, C. (1999). Entrepreneurship in the hospitality, tourism and leisure industry. Oxford: Butterworth-Heinemann.

Nickson, D. (2007).Training and development. In D. Nickson (Ed.), Human resource management for the hospitality and tourism industries (pp. 144-167). New York: Routledge.

Noble, C. (1997). International comparisons of training policies. Human Resource Management Journal, 7(1), 5-18.

Parasuraman, A., Berry, L. L., \& Zeithamal, V. A. (1988). SERVQUAL: A multi-item scale for measuring consumer perceptions of service quality. Journal of Retailing, 64(1), 12-40.

Partlow, C. G. (1996). Human-resources practices of TQM hotels. Cornell Hotel \& Restaurant Administration Quarterly, 37(5), 67-77.

Pigors, P., \& Myers. C. A. (1981). Personnel administration, a point of view and a method (09 ${ }^{\text {th }}$ Ed.). U. S. A.: McGraw-Hill.

Rigby, M. (2004). Training in Spain: An evaluation of the continuous training agreement (19932001) with particular reference to SMEs. Human Resource Development International, 7(1), 23-37.

Ronald, T. R., Stewart, G. L., Miller, H.. \& Pielack, D. (1996). The satisfaction and retention of frontline employees: A customer satisfaction measurement approach. International Journal of Service Industry Management, 7(5), 62-80.

Rousseau, D. M., \& McLean Parks, J. (1992), The contracts of individuals and organizations. Research in Organizational Behavior, 15, 1-43. 
Rust, R. T., Stewart, G. L, Miller, H., \& Pielack, D. (1996). The satisfaction and retention of frontline employees: A customer satisfaction measurement approach. International Journal of Service Industry Management, 7(5), 62-80.

Rust, R. T., \& Zahorik, A. J. (1993), Customer satisfaction, customer retention, and market share. Journal of Retailing, 69(2), 193-215.

Samaraweera, D. (2006, June 04). Small hotels to go global in IFC initiative. The Sunday Times. Retrieved from http://www.sundaytimes.lk/060604/ft/Smallhotelstogoglobal.html.

Schlesinger, L. A., \& Heskett, J. (1991). Breaking the cycle of failure in services. Sloan Management Review, 32(3). 1-17

Schneider, B., \& Bowen, D. E. (1985), Employee and customer perceptions of service in banks: Replication and extension. Journal of Applied Psychology, 70(3), 423-433.

Schneider, B., \& White, S. (2004). Service quality: Research perspective. Thousand Oaks, California: Sage Publications.

Scott, W. R., \& Meyer, J. W. (1991). The rise of training programmes in firms and agencies - An institutional perspective. Research in Organizational Behavior, 13, 297-326.

Sloman, M. (2005). Learning in knowledge-intensive organizations - Moving from training to learning. Development and Learning in Organizations: An International Journal, 19(6), 9-10.

Sommerville, K. L. (2007). Hospitality employee management and supervision: Concepts and practical applications. New Jersey: John Wiley \& Sons.

Sri Lanka Tourism Development Authority (2011). National tourism development strategy. Retrieved from http://www.sltda.lk/sites/default/files/English.pdf.

Sri Lanka Tourism Development Authority (2015). Statistical report 2015. Retrieved from http://www.sltda.gov.lk/sites/default/files/tourist-board-annual-report-2015.pdf.

Sri Lanka Tourism Development Authority. (2016). Monthly statistical bulletin 2016. Retrieved from http://www.sltda.lk/node/745.

Stoner, J. A. F., Freeman, R. E., \& Gilbert, R. (2003). Management (06 ${ }^{\text {th }}$ ed.). USA: Pearson education.

Travel Mail Reporter. (2013, January 18). Spain and Sri Lanka are best holiday destinations for value, new research finds. Daily mail.com. Retrieved from http://www.dailymail.co.uk/ travel/article-2264472/Spain-Sri-Lanka-tipped-cheapest-holiday-destinations-costssurvey.html.

Turok, I., \& Raco, M. (2000). Developing expertise in small and medium-sized enterprises: An evaluation of consultancy support. Environment and Planning C: Government and Policy, 18 (4), 409-428.

Wijesiri, L, (2010, February 27). Developing tourism in Sri Lanka and challenges. Daily News (online). Retrieved from http://archives.dailynews.lk/2010/02/27/fea03.asp. 